\title{
Size structure and geographic variation in chemical resistance of sea fan corals Gorgonia ventalina to a fungal pathogen
}

\author{
Danielle Dube*, Kiho Kim ${ }^{* *}$, Alisa P. Alker, C. Drew Harvell ${ }^{* * *}$ \\ Ecology and Evolutionary Biology, Corson Hall, Cornell University, Ithaca, New York 14853, USA
}

\begin{abstract}
Despite the intense impact of diseases on tropical marine communities, little is known about mechanisms of resistance to disease or the role of disease as a selective factor in these communities. Spatial variation in chemical resistance of Gorgonia ventalina (sea fan coral) to the fungus Aspergillus sydowii was investigated by sampling G. ventalina populations in the Florida Keys, USA, and San Salvador, Bahamas. A. sydowii is the causative agent in aspergillosis, a fungal disease affecting $G$. ventalina throughout the Caribbean. Using field census and experimental inoculation, this study examines if sea fan chemical extracts provide resistance to disease caused by A. sydowii and the potential role of disease as a selective force in shaping the chemical defenses of sea fan populations. Chemical resistance against $A$. sydowii was assessed with a fungal growth assay. Higher anti-fungal activity of small versus large fans observed in field sampling and increased disease severity in mature versus young fans in inoculation studies support the hypothesis that resistance decreases with increasing fan age. This result is also consistent with patterns predicted by the optimal defense theory and growth-differentiation balance hypotheses in plant studies. Anti-fungal activity of large sea fans increased upon inoculation, consistent with the hypothesis of inducible resistance. Anti-fungal activity of sea fan extracts from the Florida Keys and Bahamas did vary significantly with site and was negatively correlated with fan height and extract concentration (mg extract per g dry coral weight). Anti-fungal activity did not correlate significantly with disease status in a multiple regression model. The mean anti-fungal activity of sea fans varied significantly among Florida Keys but not among San Salvador sites, nor between Florida Keys and San Salvador sites. Disease pressure was not correlated with anti-fungal activity across sites, as would be expected under a simple resistance-selection model. A simple mean resistance-selection model may not be appropriate in relatively open marine systems in which environmental induction may obscure natural selection. However, the coefficient of variation in anti-fungal activity among sites is negatively correlated with disease pressure, consistent with the hypothesis that A. sydowii imposes detectable directional selection and eliminates susceptible individuals from sites with high disease pressure.
\end{abstract}

KEY WORDS: Anti-fungal resistance - Inducible resistance Natural selection - Marine diseases · Geographic variation · Gorgonia ventalina Aspergillus sydowii

\section{INTRODUCTION}

Present addresses:

*Department of Chemistry, University of California, Berkeley, Berkeley, California 94720, USA

** Department of Biology, American University, 4400 Massachusetts Ave., NW, Washington, DC 20016, USA

${ }^{* * *}$ Corresponding author. E-mail: cdh5@cornell.edu
The role of secondary compounds in mediating biological interactions of terrestrial plants is well established. Plant-herbivore and plant-pathogen interactions have been the focus of chemical ecologists (e.g. Feeny 1975, 1976, Rhoades 1979, Berenbaum et 
al. 1986, Simms \& Rausher 1989, Simms \& Fritz 1990, Goodman 1993, Mauricio \& Rausher 1997, Mauricio 1998, Agrawal et al. 1999), in part because plants rely heavily upon chemical and structural defenses. Research has focused on the ecological relevance of secondary compounds and the roles of various selective factors in shaping the chemistry of plant populations (e.g. Ellis et al. 1977, Dirzo \& Harper 1982, Berenbaum et al. 1986, Simms \& Rausher 1989, Simms \& Fritz 1990, Mauricio \& Rausher 1997, Mauricio 1998). For example, Berenbaum et al. (1986) found that parsnip webworms applied a selective force that changed the concentrations at which deterrent chemicals were present in wild parsnips (Berenbaum et al. 1986). Similarly, there is evidence that herbivores and fungal pathogens act as selective forces that favor increased glucosinolate concentrations in Arabidopsis thaliana (Mauricio \& Rausher 1997). Glucosinolate concentrations are low in populations without these enemies because of glucosinolate costs, but are high in the presence of intense selective factors through fitness benefits to A. thaliana (Mauricio \& Rausher 1997). Plant resistance is also strongly influenced by environment, one component of which is inducible resistance (Karban \& Baldwin 1997, Agrawal et al. 1999). Plant pathogen interactions have provided a particularly good system for analyses of inducible resistance. Inducible resistance to pathogens has been identified in many plant taxa and includes hypersensitive responses, oxidative bursts, chitinase, salicylic acid, proteinase inhibitors and pathogen-activated proteins (Karban \& Kuc 1999). Less is known about how selection acts on the norm of reaction for resistance and how constitutive and inducible resistance change with selection. In wild parsnips, inducible and constitutive resistance are correlated and selection favors higher inducible resistance (Zangerl \& Berenbaum 1990).

As in terrestrial habitats, benthic marine environments are often characterized by a large population of sessile, soft-bodied organisms that rely on chemical and structural means to reduce predation, competition, herbivory, and disease. Some of these invertebrates and algae produce complex mixes of secondary chemicals that may play critical roles in biological interactions (Paul 1992). For example, gorgonian corals produce a wide array of anti-bacterial (e.g. Kim 1994, Slattery et al. 1995, Jensen et al. 1996), anti-fouling (Targett et al. 1983, Standing et al. 1984, Wilsanand et al. 1999) anti-fungal (Kim et al. 2000a,b), and/or predator (e.g. Pawlik et al. 1987, Sammarco et al. 1987, Harvell et al. 1988, 1996, Harvell \& Fenical 1989, Pawlik \& Fenical 1989, Fenical \& Pawlik 1991, Van Alstyne \& Paul 1992, Cronin et al. 1995, Slattery 1999) - and competitor (e.g. Sammarco et al. 1983, Rittschoff et al. 1985, La Barre et al. 1986) — deterrent secondary compounds. Although these chemical constituents have biological activity, their ecological relevance is still under investigation, and specific ecological roles of secondary chemicals in nature are not well understood. Especially unknown are the selective pressures (i.e. predation, herbivory, disease) that have played a role in the evolution of gorgonian secondary chemicals.

For evolution by natural selection to occur, a selective pressure must act differentially on the various genotypes within a population. Studies with marine algae (e.g. Hay \& Fenical 1988, Hay et al. 1988, 1989, Hay 1998 [review], Van Alstyne \& Paul 1989, Cronin \& Hay 1996), gorgonians (e.g. Harvell \& Fenical 1989, Van Alstyne \& Paul 1992, Harvell et al. 1993, Cronin et al. 1995, Slattery 1999, Kim et al. 2000a), and sponges (e.g. Paul 1992 [review], Pawlik et al. 1995, Becerro et al. 1998, Swearingen \& Pawlik 1998) have documented significant within-species variation in secondary metabolite production. In addition, the variation in extract composition (compounds and concentrations) within an organism (Harvell \& Fenical 1989, Cronin et al. 1995, Hay et al. 1988, Kim et al. 2000a) and among populations of a single species (Hay \& Fenical 1988, Hay et al. 1989, Harvell et al. 1993) seems substantial. The roles of genotype versus environment in causing chemical variation are unknown (Harvell et al. 1993, Hay \& Fenical 1996, Hay 1998). However, analogous studies on plants have uncovered genetic variation in patterns of secondary metabolites within plant species (Berenbaum et al. 1986, Herms \& Mattson 1992 [review], Agrawal 1999), and studies on morphological traits in other colonial invertebrates have detected genetic and environmental components in induced trait values (Harvell \& Fenical 1998, Harvell 1999, Alker et al. 2000).

Observations on the changing pattern of chemical resistance across populations of a single species under selection can reveal the role of a selective agent in structuring the chemistry of host populations (Endler 1986, Jarosz \& Burdon 1991, Herms \& Mattson 1992). Geographic variation in chemical resistance will be partly the outcome of environmental variation and past selection. However, the results of strong current natural selection should be detectable, even if obscured by history. A decrease in the variation in resistance suggests that directional selection (i.e. selection for highly chemically defended individuals) is occurring (Endler 1986). Thus, under a simple resistance and selection model, strongly selected populations should show elevated chemical resistance and less variation due to the elimination of susceptible individuals from the population. Kingsolver et al. (2001) noted consistently low ability in a range of studies to detect strong directional selection in the wild. However, their review 
included no studies of pathogen impact on host resistance, a situation where strong directional selection might prevail.

Disease has been shown to be a selective agent in terrestrial plants (e.g. Simms \& Rausher 1989, Simms \& Fritz 1990, Jarosz \& Burdon 1991, 1992, Mauricio \& Rausher 1997. Shykoff et al. 1997, Mauricio 1998, Burdon \& Thrall 1999) but not yet in tropical marine species, despite community shifts due to recent mass mortalities caused by disease (reviewed by Harvell et al. 1999). A recent outbreak of aspergillosis, a fungal disease infecting Gorgonia spp. (sea fan corals) throughout the Caribbean (Nagelkerken et al. 1997a,b), provides an opportunity to assess selection on chemical disease resistance, the ability of chemical defenses to inhibit growth of the disease-causative agent. The detection of sites with relatively high disease severity compared to neighboring sites (Kim \& Harvell 2001) makes this a tractable study system for examining the role of disease as a selective agent shaping the secondary chemistry of $G$. ventalina.

Little is known about the mechanisms of coral disease resistance (Peters 1983, Richardson 1998). The identification of Aspergillus sydowii as the fungal pathogen in the current epizootic outbreak (Smith et al. 1996, Geiser et al. 1998) offers an opportunity to study local and geographic patterns in chemical resistance because the fungus grows well in culture and direct assay of anti-fungal resistance is possible (Kim et al. 2000b). Aspergillosis of sea fans is characterized by tumors, galls, tissue necrosis that leads to lesions, and purpling of the tissue (Fig. 1). In mon-

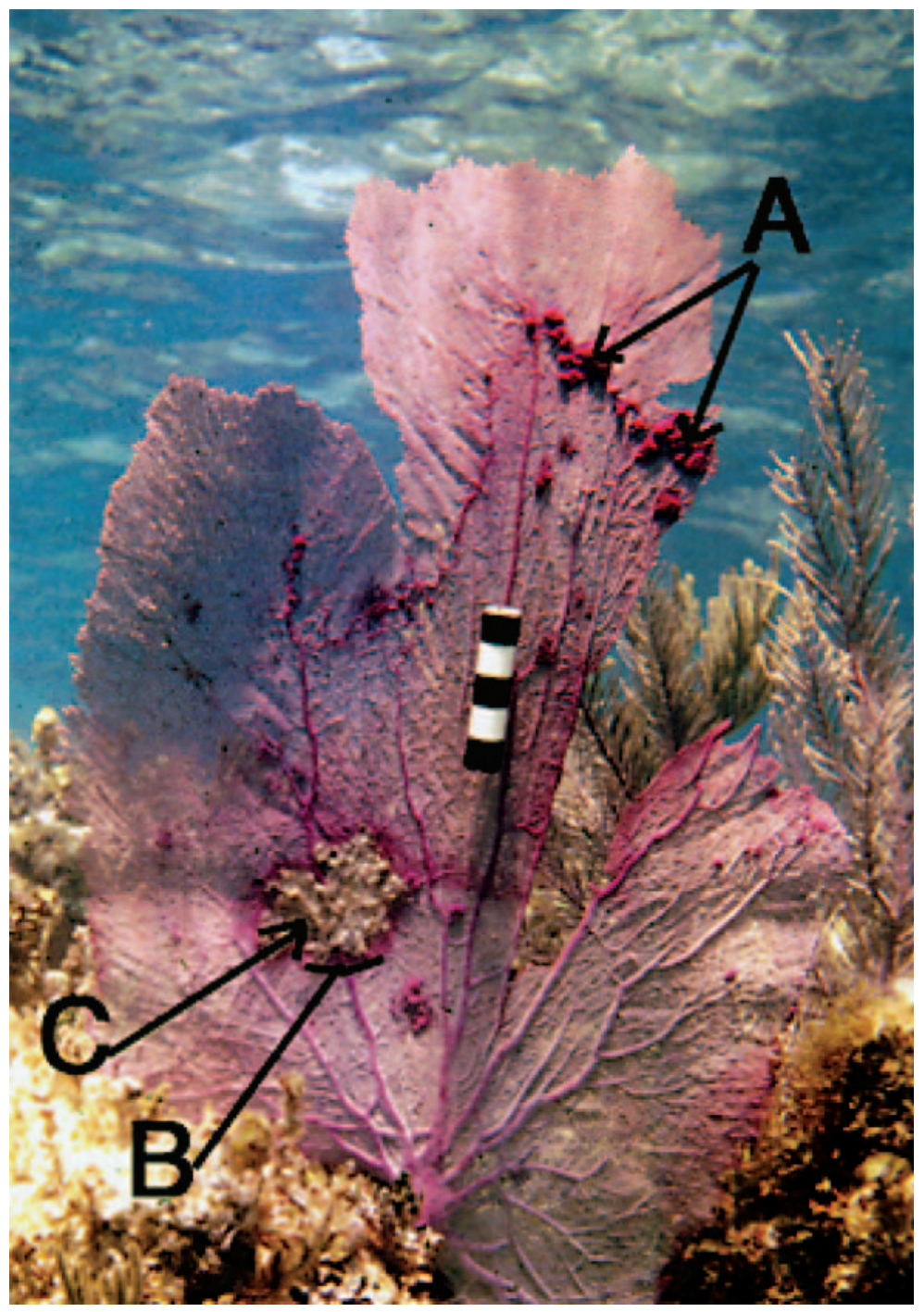

Fig. 1. Diseased Gorgonia ventalina colony from Rocky Point Reef, San Salvador, Bahamas. Disease symptoms include (A) tumors and galls, (B) purpling and (C) lesions. Photo courtesy of K.K.

itoring conducted at 5 sites in San Salvador, Bahamas, in December 1996, disease prevalence and severity were approximately $60 \%$, and prevalence was higher on larger fans (Nagelkerken et al. 1997b). In a similar monitoring survey conducted at 5 sites in the Florida Keys, USA, in 1997, disease prevalence (\% diseased sea fans) was approximately $47 \%$, disease severity (\% affected tissue per diseased colony) approximately $23 \%$, and mortality approximately $15 \%$; prevalence was again higher on larger fans (Kim \& Harvell 2001). These mortality rates are much higher than the adult colony survival rates of $95 \%$ obtained from long-term studies on gorgonian survivorship in the absence of disease (Lasker 1990), suggesting strong selection by the fungus.
Working at sites spanning the length of the Florida Keys, Florida and San Salvador, Bahamas, we tested the following hypotheses: (1) Chemical resistance is partially responsible for patterns of disease susceptibility in Gorgonia ventalina. We predicted that chemical extracts of diseased fans are less potent than healthy fans. In addition, we predicted that extracts of large fans are less potent than those of small fans, thus explaining higher disease prevalence in larger fans. (2) Local and geographic variation reflects disease selection shaping chemical defenses of sea fan populations. We predicted that colonies from sites most impacted by the disease will show higher mean and lower variation in chemical resistance than relatively unaffected sites. 


\section{MATERIALS AND METHODS}

Field component. Samples were collected (May and June 1999) from Gorgonia ventalina colonies at 9 sites in the Florida Keys, USA: Carysfort, Little Grecian Rocks, Sombrero, Molasses, Conch, Alligator, Looe, Western Dry Rocks, Marquesas Reefs (Fig. 2); and from 3 sites in San Salvador, Bahamas: Lindsey, Witches' Cauldron, Snapshot Reefs. The Florida Keys sites spanned $325 \mathrm{~km}$, and sites were on average $40 \mathrm{~km}$ apart. In contrast, the San Salvador sites were within $4 \mathrm{~km}$ of each other. Depth was approximately $7 \mathrm{~m}$ at all sites except Witches' Cauldron, a site adjacent to Snapshot Reef, where depth was 15 m. Disease prevalence varied across sites. Using SCUBA, samples were collected (approximately $4 \mathrm{~cm}^{2}$ ) from the edges of 30 haphazardly chosen colonies $(>30 \mathrm{~cm})$. A distribution of healthy and diseased colonies of variable sizes was collected at each site. For each sampled colony, height (base to tip) and disease status were noted. Diseased colonies were identified by tissue necrosis, purpling, and lesions (Fig. 1). Samples were immediately frozen on ice, transported on dry ice to Cornell University in Ithaca, NY, and stored frozen at $-20^{\circ} \mathrm{C}$ until extraction. On the same dives in the Florida Keys, data were collected on the prevalence and severity of disease on three $25 \times 2 \mathrm{~m}$ transects per site (see Kim \& Harvell 2001).

Laboratory component. To test the hypothesis that low prevalence of disease in small colonies is due to increased resistance to disease, an inoculation experiment was performed at Keys Marine Laboratory, FL, from July 9 to 17, 1999. The effects of Aspergillus sydowii on young (height $>4.3 \mathrm{~cm},<10.4 \mathrm{~cm}$ ) and mature (height $>30 \mathrm{~cm}$ ) Gorgonia ventalina colonies were determined. The designations young and mature could be confidently assessed because young colonies were just past initial recruitment and mature colonies

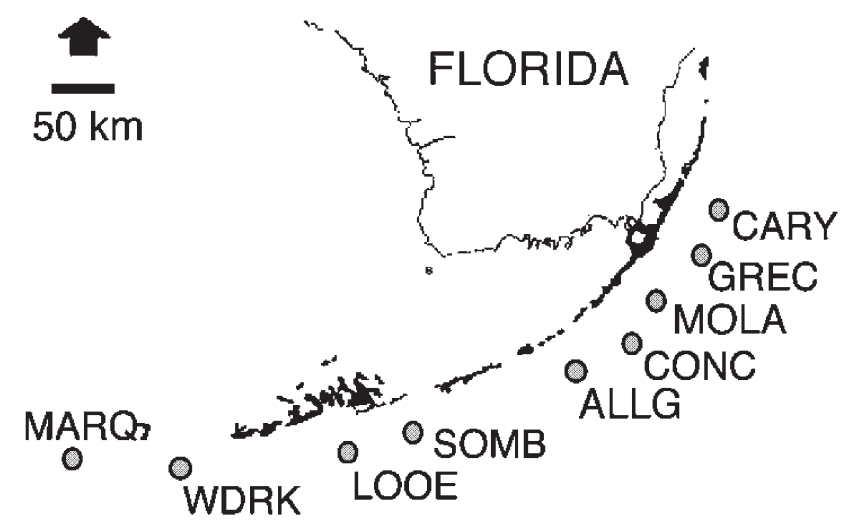

Fig. 2. Map of the Florida Keys, showing sampling sites (full site names in Table 2) were all substantially larger. Whole young colonies ( $\mathrm{n}=20$ ) and two $10 \mathrm{~cm}^{2}$ clonal replicates of each of 13 mature colonies were collected at Tennessee Reef, transferred in seawater to Keys Marine Laboratory and suspended in approximately 30001 mesocosms $(\mathrm{n}=3$ ) with flowing seawater. In each mesocosm, 6 to 7 young colonies and 8 to 10 mature colonies were suspended from lines across the mesocosms. After a short acclimation period, fans were inoculated by securing experimental gauze strips (young, $\mathrm{n}=14$; mature colonies, $\mathrm{n}=13$ ) covered with a thin layer of peptone yeast glucose) PYG agar $(0.2 \%$ peptone, $0.2 \%$ yeast extract, $0.5 \%$ glucose, $3.6 \%$ bactoagar, $0.005 \%$ Tetracycline [Calbiochem, CA]) with 3 to 5 d growth of a Key West strain of A. sydowii (identified by DNA sequence analysis by G. Smith). Control strips (young, $\mathrm{n}=6$; mature colonies, $n=13$ ) also secured via slits in the colony mesh, were covered only with a thin layer of sterile agar. Strips were removed after $2 \mathrm{~d}$, and lesion sizes were measured daily for $6 \mathrm{~d}$. At the end of the experiment, colonies were frozen on ice, transported on dry ice to the Cornell University laboratory in Ithaca, NY, and stored frozen at $-20^{\circ} \mathrm{C}$ until extraction. This successful inoculation protocol was developed through several trials in both laboratory and field settings.

The inoculation experiment also allowed us to examine the importance of anti-fungal induction in this system. Activation of high levels of resistance in response to pathogen attack would potentially obscure our ability to detect changes in constitutive levels of resistance at high pathogen sites. By measuring antifungal resistance before and after inoculation in the experiments, we could estimate the magnitude of this environmental component. The importance of inducible resistance would also be indicated if levels of antifungal activity were significantly higher in diseased than healthy corals in the survey data.

Extraction. Samples from the field collection were extracted twice for $24 \mathrm{~h}$ each in $20 \mathrm{ml}$ acetone at room temperature, then dried under reduced pressure and nitrogen. Acetone was used as the extracting solvent because of its ability to dissolve polar compounds, its volatility, and its lower toxicity to the fungus compared to ethanol. Extracts were transferred to pre-weighed scintillation vials, weighed, and subsequently stored at $-20^{\circ} \mathrm{C}$ until assayed. Remaining coral pieces were dried overnight at $60^{\circ} \mathrm{C}$ and weighed to obtain dry coral weights. The relative amount of extract per sample was standardized by calculating extract per $g$ dry coral weight (EPCW, $\mathrm{mg} \mathrm{g}^{-1}$ ).

Colonies from the inoculation experiment were extracted as above, but using dichloromethane (DCM) at $-20^{\circ} \mathrm{C}$. DCM is an effective solvent in extracting antifungal activity (Kim et al. 2001). A $4 \mathrm{~cm}^{2}$ piece of each colony, which included the site of inoculation, was 
extracted. All extracts were assayed using the procedure outlined below.

Anti-fungal growth assay. A growth assay was developed to compare the activity of different extracts against Aspergillus sydowii. Each sample, including controls, was assayed in triplicate according to the following procedure: $75 \mu \mathrm{l}$ of sample (standardized at $20 \mathrm{mg} \mathrm{ml}^{-1}$ acetone) was spread on PYG agar $(0.2 \%$ peptone, $0.2 \%$ yeast extract, $0.5 \%$ glucose, $3.6 \%$ bactoagar, $0.005 \%$ Tetracycline) in a $30 \mathrm{~mm} \times 10 \mathrm{~mm}$ petri dish. The lid was left ajar for 40 min to allow the acetone to evaporate. Preliminary tests showed that a 40 min drying time was optimal for minimizing variation $(\mathrm{SE}[40]=0.293 \mathrm{~mm})$ among replicates; it reduced solvent effects still detectable after 20 min $(\mathrm{SE}[20]=$ $0.643 \mathrm{~mm}$ ) and minimized contamination effects observed after $60 \mathrm{~min}(\mathrm{SE}[60]=0.383 \mathrm{~mm})$. The center of the plate was inoculated with $2 \mu \mathrm{l}$ of stock A. sydowii spore suspension.

Variation in fungal growth rates among assays was minimized by using a stock spore suspension (Rex et al. 1993). The stock suspension was made with spores of Aspergillus sydowii isolated from San Salvador, Bahamas (Smith et al. 1996) and filtered through gauze to remove hyphal mats and then suspended in de-ionized water at a concentration of 2150000 spores $\mathrm{ml}^{-1}$. This spore suspension was stored frozen at $-80^{\circ} \mathrm{C}$, and a fraction was thawed for each assay. To ensure that freezing the spore suspension did not reduce spore viability over time, extracts $(n=30)$ from Alligator reef were assayed against (1) fresh spore suspension (before freezing), (2) spore suspension after $14 \mathrm{~d}$ at $-80^{\circ} \mathrm{C}$, and (3) spore suspension after 4 mo. Repeatability of the assay was demonstrated because mean growth rate did not differ significantly among assays: mean(1) $=24.96 \mathrm{~mm}^{2} \mathrm{~d}^{-1}, \operatorname{mean}(2)=25.04 \mathrm{~mm}^{2} \mathrm{~d}^{-1}$, mean $(3)=25.15 \mathrm{~mm}^{2} \mathrm{~d}^{-1}$, repeated-measures ANOVA, $F=0.0076, \mathrm{df}=2, \mathrm{p}=0.9924$ ).

After $3 \mathrm{~d}$ at $25^{\circ} \mathrm{C}$, circular Aspergillus sydowii colonies were visible. Colony diameter (2 perpendicular measurements per plate) was measured at $24 \mathrm{~h}$ intervals for 3 consecutive days with a computer-integrated camera and analyzed with NIH Image 1.61 (US National Institute of Health). Because diameter growth rate of A. sydowii is approximately linear after a short lag when extract is added (Alker et al. 2001), Day 3 Day 2 area growth was used to estimate daily growth rate, where area $=\pi(\text { diameter } / 2)^{2}$. Percent area growth inhibition of A. sydowii relative to the average of noextract and acetone controls was used as a measure of extract activity.

Reproducibility of the assay was assessed in multiple controls. Each assay included 3 controls: acetone (negative control to test for solvent effect), standard (a combination of 2 Gorgonia ventalina extracts from
Little Conch Reef in the Florida Keys), and no extract. As a further check, samples from Alligator and Molasses Reef were run in multiple assays. Mean daily growth rates of Aspergillus sydowii with sea fan extract $(n=30)$ were repeatable over time for Alligator Reef: $\left(\operatorname{mean}(1)=24.96 \mathrm{~mm}^{2} \mathrm{~d}^{-1}, \operatorname{mean}(2)=\right.$ $25.04 \mathrm{~mm}^{2} \mathrm{~d}^{-1}$, mean $(3)=25.15 \mathrm{~mm}^{2} \mathrm{~d}^{-1}$; repeatedmeasures ANOVA, $F=0.0076, \mathrm{df}=2, \mathrm{p}=0.9924$ ); and for Molasses Reef: mean(1) $=23.06 \mathrm{~mm}^{2} \mathrm{~d}^{-1}$, mean $(2)=22.78 \mathrm{~mm}^{2} \mathrm{~d}^{-1}$; paired $t$-test, $t=0.420, \mathrm{df}=$ $29, \mathrm{p}=0.677$ ).

Statistical analyses. Parametric statistics were used where normality (Kolmogorov test) and homogeneity of variances (Levene test) assumptions were satisfied. Percent growth inhibition data from anti-fungal assays were natural log-transformed and lesion sizes from the inoculation experiment were natural log plus 1 transformed to satisfy parametric statistics assumptions. In cases where parametric assumptions could not be met, even with transformation, non-parametric statistics were employed. ANOVAs were conducted with Data Desk 6.0 (Velleman, Data Description), Kruskal-Wallis, Mann-Whitney and Student's t-tests with Statview 4.5 (Feldman, Gagnon, Hofmann, and Simpson, Abacus Concepts), and regression analyses with JMP 3.1.6 (SAS Institute).

\section{RESULTS}

The growth rate of Aspergillus sydowii on Gorgonia ventalina extracts averaged $21.93 \mathrm{~mm}^{2} \mathrm{~d}^{-1}$ over all samples. This was significantly lower than $37.82 \mathrm{~mm}^{2}$ $\mathrm{d}^{-1}$ observed on control plates (paired $t$-test, $t$-value $=$ $-9.616, \mathrm{df}=8, \mathrm{p}=<0.0001$ ). Thus, coral extracts inhibited the growth of $A$. sydowii by $42.0 \%$ on average, with a range of 13 to $83 \%$.

Extracts that inhibited growth of Aspergillus sydowii most were considered most active. A regression analysis was performed to test the hypothesis that extract activity across sites varied with extract per dry coral weight $\left(\mathrm{mg} \mathrm{g}^{-1}\right)$, colony height, colony disease status, and site. Regression yielded modest predictive ability (Table 1). EPCW and height were negatively related to activity, and site contributed significantly (Table 1). Disease status was not related to extract activity (Table 1).

\section{Inoculation experiment}

In laboratory mesocosm experiments, mature colonies were more affected by inoculation than were young Gorgonia ventalina colonies. Of the mature colonies, experimental and control, 46\% $(\mathrm{n}=12)$ 
Table 1. Regression of \% inhibition of Aspergillus sydowii growth rate $\left(\mathrm{mm} \mathrm{d}^{-1}\right)$ caused by sea fan extracts from sites in San Salvador and Florida Keys relative to no-extract and acetone controls. Predictive variables of fungal growth rate are extract per coral weight (EPCW, $\mathrm{mg} \mathrm{g}^{-1}$ ), colony disease status (healthy/ diseased), colony height (base/tip, $\mathrm{cm}$ ) and reef site

\begin{tabular}{|lcccrcc|}
\hline Variable & Estimate & SS & F-ratio & df & $\mathrm{p}$ & $\mathrm{R}^{2}$ \\
\hline Whole model & & 10.933 & 9.575 & 13 & $<0.0001$ & 0.28324 \\
EPCW & -0.00168 & 0.8035 & 8.866 & 1 & $<0.0001$ & \\
Disease status & -0.00319 & 0.5326 & 9.148 & 1 & 0.0027 & \\
Height & 0.03011 & 0.2218 & 6.063 & 1 & 0.0143 & \\
Site & Site-dependent & 19.108 & 2.525 & 10 & 0.113 & \\
\hline
\end{tabular}

developed lesions $>50 \mathrm{~mm}^{2}$. Of these, only one healed completely by the end of the experiment ( $8 \mathrm{~d})$. In contrast, only $10 \%(\mathrm{n}=2)$ of the young fans developed significant lesions (lesion $>24 \mathrm{~mm}^{2}<30 \mathrm{~mm}^{2}$ ), both of which healed completely by the end of the experiment. Lesions surrounding treatments on mature colonies were significantly larger than those on young colonies (Fig. 3a; Mann-Whitney, $Z=-3.357, \mathrm{p}=$ 0.0008). Experimental (E) lesions did not differ from control (C) lesions on mature (Fig. 3a; paired $t$-test, $t=-1.284, \mathrm{p}=0.2232$ ) or young (Fig. 3a; Mann Whitney $Z=-1.353, \mathrm{p}=0.1761$ ) colonies. Extract activity did not differ among mature $(\mathrm{M})$ and young $(\mathrm{Y})$ colonies (Fig. 3b; Mann-Whitney $Z=-0.313, \mathrm{p}=$ 0.7543) or among treatment types $(E, C)$ applied to young colonies (Fig. 3b; Mann-Whitney $Z=-0.040$, $p=0.9604)$. However, extract activity was significantly higher in $\mathrm{E}$ vs $\mathrm{C}$ samples from mature colonies (Fig. 3b; paired $t$-test, $t=-2.606, \mathrm{p}=0.0285$ ).
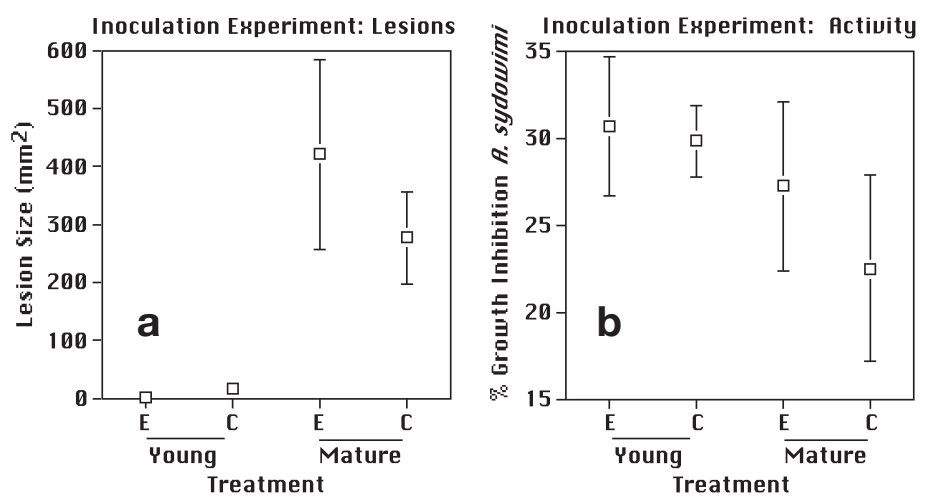

Fig. 3. Gorgonia ventalina. Results of $8 \mathrm{~d}$ inoculation experiment. (a) Mean $( \pm 1 \mathrm{SE})$ lesion size $\left(\mathrm{mm}^{2}\right)$ on young $(\mathrm{n}=20)$ and mature $(n=26)$ colonies from experimental $(E)$ and control (C) treatments; (b) mean $( \pm 1 \mathrm{SE})$ antifungal activity of extracts from young and mature colonies after experimental (E) and control (C) treatments. Extract activity is \% growth inhibition of Aspergillus sydowii relative to no-extract and acetone controls

\section{Local and geographic variation in extract activity}

Mean inhibition of fungal growth rate (Kruskal-Wallis $H=101.738, \mathrm{p}<$ $0.0001, \mathrm{df}=8$ ) and variance in growth rate (Levene test, $F=2.262, \mathrm{p}=0.0236$ ) varied across sites in the Florida Keys (Fig. 4). Neither mean fungal growth rate inhibition (1-way ANOVA, $F=$ $0.7897, \mathrm{p}=0.4572$ ) nor growth rate variance (Levene test, $F=0.2129$, $\mathrm{p}=0.886)$ varied across sites in San Salvador (Fig. 4).

Disease pressure (disease prevalence $\times$ disease severity, after Goldberg \& Makemson 1981) did not significantly correlate with the mean activity characterizing each site (Fig. 5 ; regression $\mathrm{R}^{2}=0.029$, F-ratio $=0.206, \mathrm{df}=7, \mathrm{p}=0.6637)$. However to test the hypothesis that disease severity was correlated with variation in activity at a site, the effect of disease pressure on the coefficients of variation of activity characterizing each site was analyzed by regression. Variation is negatively related $(p<0.10)$ to disease pressure (Fig. 6 ; regression $\mathrm{R}^{2}=0.3989, \mathrm{df}=7, F$-ratio $\left.=4.63, \mathrm{p}=0.0685\right)$.

\section{DISCUSSION}

Chemical constituents of Gorgonia ventalina probably play a role in resistance to aspergillosis. On average, G. ventalina extracts inhibited growth rate of

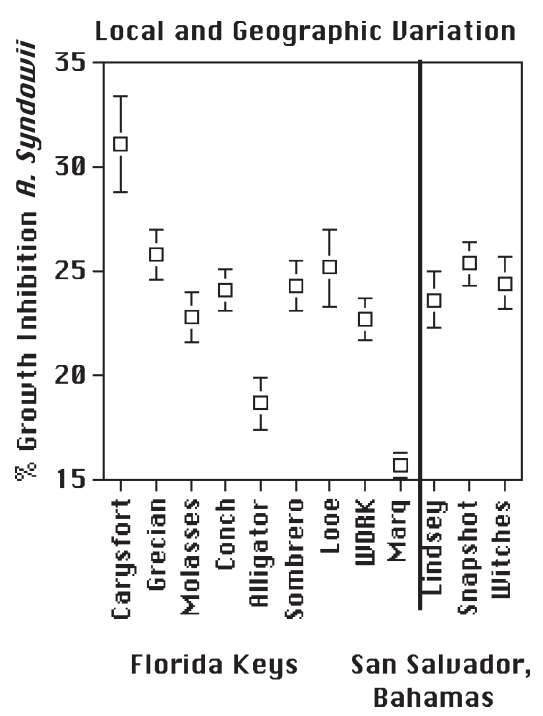

Fig. 4. Aspergillus sydowii. Mean $( \pm 1 \mathrm{SE})$ percent growth inhibition caused by Gorgonia ventalina extracts ( $\mathrm{n}=30 /$ site) from sites in the Florida Keys and San Salvador. Florida Keys sites are shown (left to right) from upper to lower Keys 


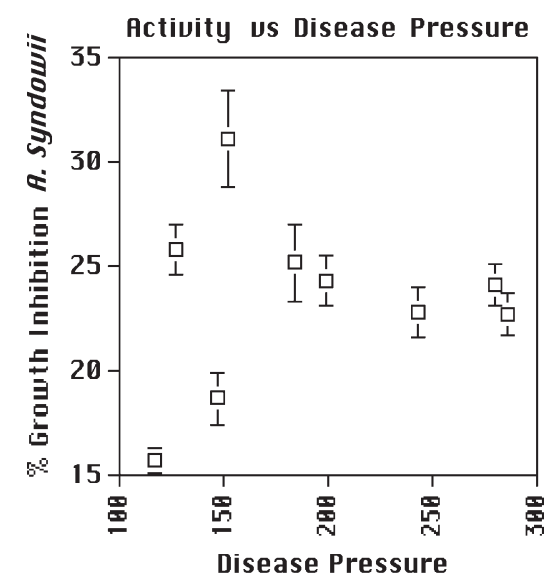

Fig. 5. Gorgonia ventalina. Mean $( \pm 1 \mathrm{SE})$ activity of sea fan extracts vs disease pressure (disease prevalence $\times$ disease severity) associated with each Florida Keys site. Extract activity is \% growth inhibition of Aspergillus sydowii relative to no-extract and acetone controls

Aspergillus sydowii by $42 \%$ compared to controls. However, the degree of inhibition varied significantly among colonies (13 to $83 \%$ ); if genetically based, this is variation which selection by disease may act upon. Some of the variation in resistance is correlated with ecologically relevant parameters, including fan height, geographic location, and extract per coral weight (Table 1). Anti-fungal activity against A. sydowii, is negatively related to EPCW (Table 1). Sea fans with a relatively low mass of extract generally had high activity.

The impact of aspergillosis on sea fans is magnified because large colonies, which normally add disproportionately to the reproductive pool (e.g. Brazeau \&

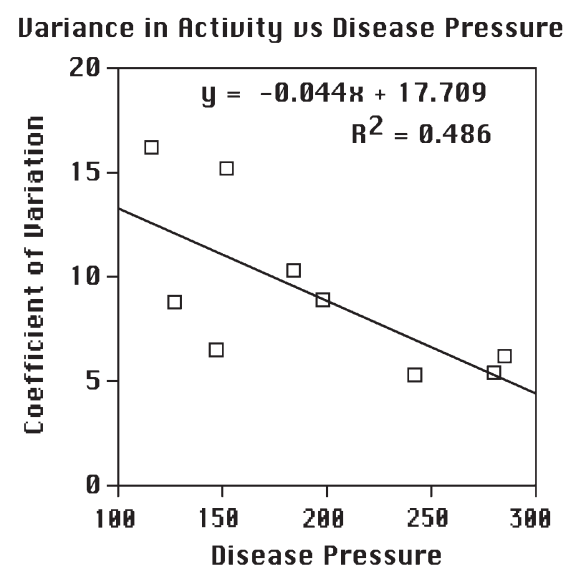

Fig. 6. Gorgonia ventalina. Regression of coefficient of variation in sea fan extract activity on disease pressure (disease prevalence $\times$ disease severity) associated with each Florida Keys site. Extract activity is \% growth inhibition of Aspergillus sydowii relative to no-extract and acetone controls
Lasker 1990), are being affected more severely than are sea fans of smaller size classes (Nagelkerken et al. 1997b, Kim \& Harvell 2001). Three hypotheses to explain increased disease prevalence in large fans are: (1) a positive relationship between probability of infection and surface area, (2) a greater age and hence longer exposure time of large fans relative to small fans, and (3) greater chemical, cellular, and/or structural resistance to the disease in small fans relative to large fans (size-specific defense). In support of the size-specific defense hypothesis, extract activity was negatively correlated with fan height among the survey fans (Table 1). Higher anti-fungal activity measured in smaller colonies indicates that size-specific defense explains some of the bias in disease prevalence patterns towards larger colonies, although both longer exposure time and greater exposure area of larger fans are also likely to contribute.

The inoculation experiment comparing mature vs young fans is an experimental approach to assessing the size-specific defense hypothesis. Since identical treatments in the same tanks were applied for equivalent lengths of time, any response differences between mature and young colonies to treatments cannot be explained by either the surface area or exposure time hypotheses. Young fans were much more resistant to developing lesions associated with the inoculation treatment than mature fans (Fig. 3a). Young colonies in the mesocosms had both higher levels of anti-fungal activity and were more resistant than mature colonies to inoculation treatments (Fig. 3a,b). The anti-fungal data also shows an increase in anti-fungal chemistry of clonal pieces of mature fans exposed to Aspergillus sydowii, suggesting induction of resistance in mature colonies (Fig. 3b). Induction of resistance in mature colonies is consistent with Kim et al.'s (2000a) finding that anti-fungal activity was elevated surrounding $A$. sydowii lesions, and possibly consistent with Slattery's (1999) finding that the chemical composition of extracts from diseased fans differed from healthy fans. Alker (2000) also detected an induced structural response in diseased sea fans.

Size-specific defenses are a common pattern in plants and are explained by 2 theories. In plants, concentrations of some secondary metabolites are highest during early stages of seedling growth and leaf expansion, and/or are synthesized only in young tissue (Cates \& Rhoades 1977, Puttick 1986, Porter et al. 1992). Optimal defense theory states that chemical defenses are allocated in accordance with tissue value. An extension of this theory to sea fans would suggest that small fans should be more chemically defended than large fans due to the relative tissue value of small versus large fans. A tissue value argument seems particularly plausible in this case because infected small colonies 
would suffer a greater proportional partial mortality loss than large fans if diseased. Thus, the benefits of defending a colony are likely to be greater for small than for large colonies. Another possible explanation is the growth-differentiation balance (GDB) hypothesis (Loomis 1932). The GDB hypothesis posits a tradeoff between growth and plant defenses, which could lead to an inverse relationship between plant size and defenses among plants of similar age classes. This theory predicts that among fans of similar age classes, large sea fans are disproportionately represented by rapidly growing, poorly defended individuals, whereas small fan height classes are disproportionately represented by slow-growing, well-defended individuals. Correlation between growth rate and level of resistance cannot be resolved here without growth rate data. Thus, greater resistance of small fans may arise from either greater selection for defense in small individuals or from an accumulation of resistant individuals in small size classes.

Inoculation experiments provided evidence for induction of resistance in large fans. From this we predicted that diseased fans in the census would have higher levels of anti-fungal activity than healthy fans. Disease status did not have a significant predictive power in determining activity in the whole-model regression (Table 1). However, the contribution of genotype and environment cannot be disentangled in the census data. For example, the pattern we observed could result if constitutively more susceptible fans became infected first but, by the time of the census, had exhibited an induced response that brought them to levels comparable to uninfected fans.

As initially hypothesized, anti-fungal activity varies significantly among sites in the Florida Keys. With the exception of Looe Key, the activity decreases from upper to lower Florida Keys (Fig. 4), with one of the most extreme differences being observed between Carysfort, the uppermost and most active site, and Marquesas, the lowermost and least active site. In contrast to the Florida Keys, no significant variation was observed among sites in San Salvador (Fig. 4). This may be due, at least in part, to the difference in scale of site comparison. The Florida Keys sites spanned $325 \mathrm{~km}$, and sites were an average distance of $40 \mathrm{~km}$ apart. In contrast, the San Salvador sites were within $4 \mathrm{~km}$ of each other, and thus may not represent significantly different genetic pools or environments. However, other species of gorgonians do vary chemically and genetically across extremely short spatial scales. Gene frequencies and secondary chemistry in Briareum asbestinum varies even across a $10 \mathrm{~m}$ depth cline and shows large spatial variation (Harvell et al. 1993, Brazeau \& Harvell 1994). Local variation was not observed across a depth cline in sea fan anti-fungal activity in San Salvador. In the Witches' Cauldron/ Snapshot comparison, activity and variation levels did not vary significantly with depth (Fig. 4). This result suggests that the increase in disease prevalence and severity observed with increasing water depth (Nagelkerken et al. 1997a,b) are not explainable by differences in chemical resistance, at least not at these sites in San Salvador.

Under a hypothesis of natural selection by disease, populations of sea fans are predicted to have the highest activity and lowest variation at sites most impacted by aspergillosis. In this study, the mean activity level did not correlate with disease pressure: in the Keys the 2 extreme activity sites, Carysfort \& Marquesas, have similar disease pressures (Fig. 4 \& Table 2) which are among the lowest (Fig. 5) we recorded. However the variance in anti-fungal activity did correlate strongly across sites as a function of disease pressure (Fig. 6). Sites with the highest disease pressure had low variation in anti-fungal activity (Fig. 6), consistent with the predicted effect of selection. Ultimately the ability to detect natural selection acting on sea fan resistance will depend on the degree of differential mortality and the degree of genetic mixing among sites. Because these are partially open marine systems with dispersing larvae (Thorson 1950, Palumbi 1992, Warner 1997), mixing will counteract effects of selection and make it less detectable.

Natural selection on phenotypic characters has been detected previously in wild populations. Male guppies evolved delayed maturity and larger size at maturity within 4 yr of exposure to predation pressures (Reznick et al. 1997). Galápagos finch populations, which experienced mortality rates of $85 \%$ due to draught, displayed significant changes in beak width within a year (Grant \& Grant 1995). Despite these and many more successes in estimating selection, Kingsolver et al. (2001) emphasize difficulty in detecting strong direc-

Table 2. Disease parameters measured at sites in the Florida Keys in May 1999 (Kim \& Harvell unpubl. data). Disease prevalence: mean \% diseased fans; disease severity: mean $\%$ of fan diseased; disease pressure: disease severity $\times$ disease prevalence

\begin{tabular}{|lccc|}
\hline Site & $\begin{array}{c}\text { Disease } \\
\text { severity }\end{array}$ & $\begin{array}{c}\text { Disease } \\
\text { prevalence }\end{array}$ & $\begin{array}{c}\text { Disease } \\
\text { pressure }\end{array}$ \\
\hline Carysfort & 16.2 & 9.4 & 152 \\
Grecian & 15.1 & 8.4 & 127 \\
Alligator & 6.8 & 21.6 & 147 \\
Conch & 15.7 & 17.8 & 280 \\
Sombrero & 8.8 & 22.7 & 199 \\
Molasses & 20.5 & 11.8 & 243 \\
Looe & 12.4 & 14.9 & 184 \\
WDRK & 14.9 & 19.1 & 286 \\
Marquesas & 10.1 & 11.5 & 117 \\
\hline
\end{tabular}


tional selection in the wild. However, there are currently no quantitative estimates of selection and rates of evolution of resistance for host-pathogen systems in the wild. Mortality levels due to aspergillosis were estimated to exceed $20 \%$ per year at some sites in the Florida Keys (Kim \& Harvell 2001); current estimates are far higher. This level of mortality, if it is differential with respect to coral resistance, is sufficiently strong to affect variance in resistance. In addition to mortality, selection is also imposed by disease impact on coral fitness, which is probably large when severity (percent of a coral colony damaged) exceeds $50 \%$. In colonial organisms, partial mortality is often just as or more important than colony mortality (Hughes \& Jackson 1985, Alker 2000). Diseases with low mortality yet high prevalence and severity can have stronger selective impacts on populations than high mortality diseases (McCallum \& Dobson 1995).

The absence of a correlation between mean resistance level and disease pressure is not surprising, even if selection is strong (Fig. 5). Counteracting the ability to detect selection on chemical activity are the degree of genetic mixing among sites (Warner 1997) and environmental effects on sea fan chemical defenses. Sea fan genetic structure and larval dispersal potential are unknown, but sea fan larvae are thought to disperse relatively far in this species. One possibility is that the level of chemical activity observed among sites in the Florida Keys is the result of local genetic differentiation. Even among widely dispersing marine species, differentiation of local populations is common in marine systems (Hedgecock 1986, Warner 1997) and is particularly detectable among philopatrically dispersing gorgonians (Brazeau \& Lasker 1990, Harvell et al. 1993, Brazeau \& Harvell 1994). Such differentiation can occur despite gene flow when there is strong postsettlement selection (Burton \& Feldman 1982, Jablonski \& Lutz 1983, Hedgecock 1986) or differential larval dispersal (Hedgecock 1986, Sammarco \& Andrews 1989, Hughes et al. 1999, Yu et al. 1999). Thus, both past and current selective forces may have caused the anti-fungal activity observed at each site and historical selection may be limiting our ability to observe current selection. Finally, as in many studies, we are basing our ranking of disease pressure on a single time interval (although this variable should integrate over at least short time scales) and cannot rule out the likely possibility that disease pressure fluctuates over time among sites.

Inducible activation of antifungal resistance could also obscure detection of natural selection. There is a strong indication from this study and others (Alker 2000, Harvell et al. unpubl. data) that increased antifungal resistance in sea fans is induced by Aspergillosis sydowii. Thus, differences in chemical activity observed among sites could also be influenced by other environmental factors (e.g. water quality parameters such as turbidity, nitrate levels [Fleury et al. 2000], temperature, or previous pathogen attack). High levels of phenotypic plasticity can significantly inhibit the detectability of natural selection. In plants, a correlation between levels of induced and constitutive resistance has only been found in wild parsnips (Zangerl \& Berenbaum 1990), and not in other plants assayed (Brody \& Karban 1992, Thaler \& Karban 1997, EnglishLoeb et al. 1998). Also in wild parsnips, induced resistance is sensitive to environmental factors including productivity, shading and type of biotic cue (Berenbaum \& Zangerl 1999). Levels of inducible and constitutive resistance have not been assayed in the traits of most colonial invertebrates. For morphological defenses of colonial invertebrates, Harvell (1998) showed that the length of both induced and constitutive defensive spines in bryozoans varies with clone. Understanding the relative contribution of induced and constitutive resistance to fungi in sea fans is fundamental to the ability to eventually detect selection on resistance (Harvell et al. unpubl. data). Although selective factors can have a detectable impact on the mean trait values of some populations over even a single generation (e.g. Dirzo \& Harper 1982, Berenbaum et al. 1986, Simms \& Rausher 1989, Marquis 1990, Simms \& Fritz 1990, Grant \& Grant 1995, Mauricio \& Rausher 1997, Reznick et al. 1997, Yunchang et al. 1999), strong environmental effects on plant and coral resistance may reduce the likelihood of detecting changes in the means. However, the strong correlation we detected between low variance in resistance and high disease pressure suggests that natural selection by the pathogen A. sydowii may be detectable.

Acknowledgements. This work was supported by funds from the Howard Hughes Foundation for undergraduate research to D.D.; Cornell University undergraduate honors thesis research funds to D.D.; NSF-OCE-9818830 and NURCUNCW 9821 to C.D.H. and K.K. Portions of this work were carried out under Bahamian Department of Agriculture Permit 96-020, United States National Marine Sanctuary Permit FKNMS-268-97 and Florida Department of Environmental Protection Permit 98S-334. The staff at the NOAA-NURC facility in Key Largo, and the staff at the Bahamian Field Station in San Salvador, Bahamas, are gratefully acknowledged for logistic support of this work. J. C. Clardy and M. Wagenaar are greatly appreciated for providing guidance on chemistry laboratory techniques and laboratory space. Comments on the manuscript from N. Hairston, J. Ward, P. Feeny, K. Hayden and other colleagues are gratefully acknowledged.

\section{LITERATURE CITED}

Agrawal AA (1999) Induced plant defense: evolution of induction and adaptive phenotypic plasticity. In: Agrawal AA, Tuzun S, Bent E (eds) Induced plant defenses against 
pathogens and herbivores: biochemistry, ecology and agriculture. American Phytopathological Society Press, St. Paul, MN, p 251-268

Agrawal AA, Tuzun S, Bent E (eds) (1999) Induced plant defenses against pathogens and herbivores: biochemistry, ecology and agriculture. American Phytopathological Society Press, St. Paul, MN

Alker AP (2000) The induction of a physical response in sea fans to competitors, predators and pathogens. MSc thesis, Cornell University, Ithaca, NY

Alker AP, Smith GW, Kim K (2001) Characterization of Aspergillus sydowii (Thom et Church), a fungal pathogen of Caribbean sea fan corals. Hydrobiologia 460:105-111

Becerro MA, Paul VJ, Starmer J (1998) Intracolonial variation in chemical defenses of the sponge Cacospongia sp. and its consequences on the generalist fish predator and the specialist nudibranch predator Glossodoris pallida. Mar Ecol Prog Ser 168:187-196

Berenbaum MR, Zangerl AR (1988) Stalemates in the coevolutionary arms race: syntheses, synergisms, and sundry other sins. In: Spencer KC (ed) Chemical mediation of coevolution. Academic Press, San Diego, p 113-132

Berenbaum MR, Zangerl AR (1999) Coping with life as a menu option: inducible defenses of the wild parsnip. In: Tollrian R, Harvell CD (eds) The ecology and evolution of inducible defenses. Princeton University Press, Princeton, NJ, p 10-32

Berenbaum MR, Zangerl AR, Nitao JK (1986) Constraints on chemical coevolution: wild parsnips and the parsnip webworm. Evolution 40:1215-1228

Brazeau DA, Harvell CD (1994) Genetic structure of local populations and divergence between growth forms in a clonal invertebrate, the Caribbean octocoral Briareum asbestinum (Pallas). Mar Biol 119:53-60

Brazeau DA, Lasker HR (1990) Sexual reproduction and external brooding by the Caribbean gorgonian Briareum asbestinum. Mar Biol 104:465-474

Brody AK, Karban R (1992) Lack of tradeoff between constitutive and induced defense among varieties of cotton. OIKOS 65:301-306

Burdon JJ, Thrall PH (1999) Spatial and temporal patterns in coevolving plant and pathogen associations. Am Nat 153: S15-S33

Burton RS, Feldman MW (1982) Population genetics of coastal and estuarine invertebrates: does larval behavior influence population structure? In: Kennedy VS (ed) Estuarine comparisons. Academic Press, New York, p 537-551

Cates RG, Rhoades DF (1977) Prosopis leaves as a resource for insects. In: Simpson BB (ed) Mesquite: its biology in two desert scrub ecosystems. International Biological Progress Series, Vol 4. Academic Press, New York, p 61-83

Cronin G, Hay ME (1996) Induction of seaweed chemical defenses by amphipod grazing. Ecology 77:2287-2301

Cronin G, Hay ME, Fenical W, Lindquist N (1995) Distribution, density, and sequestration of host chemical defenses by the specialist nudibranch Tritonia hamnerorum found at high densities on the sea fan Gorgonia ventalina. Mar Ecol Prog Ser 119:177-189

Dirzo R, Harper JL (1982) Experimental studies on slug-plant interactions. III. Differences in the acceptability of individual plants of Trifolium repens to slugs and snails. J Ecol 70:101-117

Endler JA (1986) Natural selection in the wild. Princeton University Press, Princeton, NJ

English-Loeb G, Karban R, Walker MA (1998) Genotypic variation in constitutive and induced resistance in grapes against spider mite (Acari: Teranychidae) herbivores. Environ Entomol 27:297-304

Feeny P (1975) Biochemical coevolution between plants and their insect herbivores. In: Gilbert LE, Raven PH (eds) Coevolution of animals and plants. University of Texas Press, Austin, TX, p 1-19

Feeny P (1976) Plant apparency and chemical defense. Recent Adv Phytochem 10:1-40

Fenical W, Pawlik JR (1991) Defensive properties of secondary metabolites from the Caribbean gorgonian coral Erythropodium caribaeorum. Mar Ecol Prog Ser 75:1-8

Fleury BG, Coll JC, Tentori E, Duquesne S, Figueiredo L (2000) Effect of nutrient enrichment on the complementary (secondary) metabolite composition of the soft coral Sarcophyton ehrenbergi (Cnidaria: Octocorallia: Alcyonaceae) of the Great Barrier Reef. Mar Biol 136:63-68

Geiser DM, Taylor JW, Ritchie KB, Smith GW (1998) Cause of sea fan death in the West Indies. Nature 394:137-138

Goodman BA (1993) The involvement of oxygen-derived free radicals in plant-pathogen interactions. Proc R Soc Edinb Sect B (Biol) 102:479-493

Grant PR, Grant BR (1995) Predicting microevolutionary responses to directional selection on heritable variation. Evolution 49:241-251

Harvell CD (1998) Genetic variation and polymorphism in the inducible spines of a marine bryozoan. Evolution 52:80-86

Harvell CD (1999) Complex biotic environments, coloniality and heritable variation for inducible defenses. In: Tollarian R, Harvell CD (eds) The ecology and evolution of inducible defenses. Princeton University Press, Princeton, NJ, p 231-244

Harvell CD, Fenical W (1989) Chemical and structural defenses of Caribbean gorgonians (Pseudopterogorgia spp.): intracolony localization of defense. Limnol Oceanogr 34: 382-389

Harvell CD, Fenical W, Greene CH (1988) Chemical and structural defenses of Caribbean gorgonians (Pseudopterogorgia spp.). I. Development of an in situ feeding assay. Mar Ecol Prog Ser 49:287-294

Harvell CD, Fenical W, Roussis V, Ruesink JL, Griggs CC, Greene CH (1993) Local and geographic variation in the defensive chemistry of a West Indian gorgonian coral (Briareum asbestinum). Mar Ecol Prog Ser 93:165-173

Harvell CD, West JM, Griggs C (1996) Chemical defense of embryos and larvae of a West Indian gorgonian coral, Briarium asbestinum. Invertebr Reprod Dev 30:239-246

Harvell CD, Kim K, Burkholder JM, Colwell RR and 9 others (1999) Emerging marine diseases-climate links and anthropogenic factors. Science 285:1505-1510

Hay ME (1998) Marine chemical ecology: what's known and what's next? J Exp Mar Biol Ecol 20:103-134

Hay ME, Fenical W (1988) Marine plant-herbivore interactions: the ecology of chemical defense. Annu Rev Ecol Syst 19:111-145

Hay ME, Fenical W (1996) Chemical ecology and marine biodiversity: insights and products from the sea. Oceanography (Wash) 9:10-20

Hay ME, Paul VJ, Lewis SM, Gustafson K, Tucker J, Trindell RN (1988) Can tropical seaweeds reduce herbivory by growing at night? Diel patterns of growth nitrogen content herbivory and chemical versus morphological defenses. Oecologia 75:233-245

Hay ME, Duffy JE, Fenical W (1989) Seaweed chemical defenses: among-compound and among-herbivore variance. Proc 6th Int Coral Reef Symp 3:43-48

Hedgecock D (1986) Is gene flow from pelagic larval dispersal 
important in the adaptation and evolution of marine invertebrates? Bull Mar Sci 39:550-564

Herms DA, Mattson WJ (1992) The dilemma of plants: to grow or to defend. Q Rev Biol 67:283-335

Hughes TP, Jackson JBC (1985) Population dynamics and life histories of foliaceous corals. Ecol Monogr 55:141-166

Hughes TP, Baird AH, Dinsdale EA, Moltschaniwskyj NA and 3 others (1999) Patterns of recruitment and abundance of corals along the Great Barrier Reef. Nature 397:59-63

Jablonski D, Lutz RA (1983) Larval ecology of marine benthic invertebrates: paleobiological implications. Biol Rev (Camb) 58:21-89

Jarosz AM, Burdon JJ (1991) Host-pathogen interactions in natural populations of Linum marginale and Melampsora lini. II. Local and regional variation in patterns of resistance and racial structure. Evolution 45:1618-1627

Jarosz AM, Burdon JJ (1992) Host-pathogen interactions in natural populations of Linum marginale and Melampsora lini. III. Influence of pathogen epidemics on host survivorship and flower production. Oecologia 89:53-61

Jensen PR, Harvell CD, Wirtz K, Fenical W (1996) Antimicrobial activity of extracts of Caribbean gorgonian corals. Mar Biol 125:411-419

Karban R, Baldwin I (1997) Induced responses to herbivory. University of Chicago Press, Chicago

Karban R, Kuc J (1999) Induced resistance against pathogens and herbivores: an overview. In: Agrawal AA, Tuzun S, Bent E (eds) Induced plant defenses against pathogens and herbivores: biochemistry, ecology and agriculture. American Phytopathological Society Press, St. Paul, MN

Kim K (1994) Antimicrobial activity in gorgonian corals (Coelenterata, Octocorallia). Coral Reefs 13:75-80

Kim K, Harvell CD (2001) Aspergillosis of sea fan corals: disease dynamics in the Florida Keys, USA. In: Porter KG, Porter J (eds) Linkages among ecosystems in the Florida Hydroscape. CRC Press, Boca Raton, FL, p 813-823

Kim K, Harvell CD, Kim PD, Smith W, Merkel SM (2000a) Role of secondary chemistry in fungal disease resistance of sea fans. Mar Biol 136:259-267

Kim K, Kim PD, Alker AP, Harvell CD (2000b) Antifungal properties of gorgonian corals. Mar Biol 137:393-401

Kingsolver J, Hoekstra HE, Hoekstra JM, Berrigan D and 5 others (2001) The strength of phenotypic selection in natural populations. Am Nat 157:245-261

La Barre SC, Coll JC, Sammarco PW (1986) Competitive strategies of soft corals (Coelenterata: Octocorallia). III. Spacing and aggressive interactions between alcyonaceans. Mar Ecol Prog Ser 28:147-156

Lasker HR (1990) Clonal propagation and population dynamics of a gorgonian coral. Ecology 71:1578-1589

Loomis WE (1932) Growth-differentiation balance vs. carbohydrate-nitrogen ratio. Proc Am Soc Hortic Sci 29:240-245

Marquis RJ (1990) Genotypic variation in leaf damage in Piper arieianum (Piperaceae) by a multispecies assemblage of herbivores. Evolution 44:104-120

Mauricio R (1998) Costs of resistance to natural enemies in field populations of the annual plant Arabidopsis thaliana. Am Nat 151:20-28

Mauricio R, Rausher MD (1997) Experimental manipulation of putative selective agents provides evidence for the role of natural enemies in the evolution of plant defense. Evolution 51:1435-1444

McCallum H, Dobson A (1995) Detecting disease and parasite threats to endangered species and ecosystems. Trends Ecol Evol 10:190-194

Nagelkerken I, Buchan K, Smith GW, Bonair K and 10 others (1997a) Widespread disease in Caribbean sea fans. I.
Spreading and general characteristics. Proc 8th Int Coral Reef Symp 1:679-682 (Lessios HA, Macintyre IG [eds] Smithonian Tropical Research Institute, Panamá)

Nagelkerken I, Buchan K, Smith GW, Bonair K and 10 others (1997b) Widespread disease in Caribbean sea fans. II. Patterns of infection and tissue loss. Mar Ecol Prog Ser 160: 225-263

Palumbi SR (1992) Marine speciation on a small planet. Trends Ecol Evol 7:114-118

Paul VJ (1992) Chemical defenses of benthic marine invertebrates. In: Paul VJ (ed) Ecological roles of marine natural products. Cornell University Press, Ithaca, NY, p 164-188

Pawlik JR, Fenical W (1989) A re-evaluation of the ichthyodeterrent role of prostaglandins in the Caribbean gorgonian coral Plexaura homomalla. Mar Ecol Prog Ser 52:95-98

Pawlik JR, Burch MT, Fenical W (1987) Patterns of chemical defense among Caribbean gorgonian corals: a preliminary survey. J Exp Mar Biol Ecol 108:55-66

Pawlik JR, Chanas B, Toonen RJ, Fenical W (1995) Defenses of Caribbean sponges against predatory fish. I. Deterrency. Mar Ecol Prog Ser 127:183-194

Peters EC (1983) The role of environmental stress in the development of coral diseases and micro parasite infestations. Am Zool 23:960

Porter JW, Meier OW (1992) Quantification of loss and change in Floridian coral populations. Am Zool 32:625-640

Puttick GM (1986) Utilization of evergreen and deciduous oaks by the Californian oak moth Phryganidia californica. Oecologia 68:589-594

Rex JH, Pfaller MA, Rinaldi MG, Polak A, Galgiani JN (1993) Anti-fungal susceptibility testing. Clin Microbiol Rev 6: 367-381

Reznick DN, Shaw FH, Rodd FH, Shaw RG (1997) Evaluation of the rate of evolution in natural populations of guppies (Poecilia reticulata). Science 275:1934-1938

Rhoades DF (1979) Evolution of plant chemical defense against herbivores. In: Rosenthal GA, Janzen DH (eds) Herbivores: their interactions with secondary plant metabolites. Academic Press, New York, p 3-54

Richardson LL (1998) Coral diseases: what is really known? Trends Ecol Evol 13:438-443

Rittschoff D, Hooper IR, Branscomb ES, Costlow JD (1985) Inhibition of barnacle settlement and behavior by natural products from whip corals Leptogorgia virgulata (Lammarck, 1815). J Chem Ecol 11:551-563

Sammarco PW, Andrews JC (1989) The Helix experiment: differential localized dispersal and recruitment patterns in Great Barrier Reef corals. Limnol Oceanogr 34:896-912

Sammarco PW, Coll JC, La Barre S, Willis B (1983) Competitive strategies of soft corals (Coelenterata: Octocorallia): allelopathic effects on selected scleractinian corals. Coral Reefs 1:173-178

Sammarco PW, La Barre S, Coll JC (1987) Defensive strategies of soft corals (Coelenterata: Octocorallia): allelopathic effects on selected scleractinian corals. Coral Reefs 1: 173-178

Shykoff JA, Bucheli E, Kaltz O (1997) Anthur smut disease in Dianthus silvester (Caryophyllaceae): natural selection of floral traits. Evolution 51:383-392

Simms EL, Fritz RS (1990) The ecology and evolution of hostplant resistance to insects. Trends Ecol Evol 5:356-360

Simms EL, Rausher MD (1989) The evolution of resistance to herbivory in Ipomoea purpurea. Natural selection by insects and costs of resistance. Evolution 43:573-585

Slattery M (1999) Fungal pathogenesis of the sea fan Gorgonia ventalina: direct and indirect consequences. Chemoecology 9:97-104 
Slattery M, McClintock JB, Heine JN (1995) Chemical defenses in Antarctic soft corals: evidence for antifouling compounds. J Exp Mar Biol Ecol 190:61-77

Smith G, Ives LD, Nagelkerken IA, Ritchie KB (1996) Caribbean sea fan mortalities. Nature 383:p 487

Standing JD, Hooper IR, Costlow JD (1984) Inhibition and induction of barnacle settlement by natural products present in octocorals. J Chem Ecol 10:823-834

Swearingen DC III, Pawlik JR (1998) Variability in the chemical defense of the sponge Chondrilla nucula against predatory reef fishes. Mar Biol 131:619-627

Targett NM, Bishop SS, McConnel OJ, Yoder JA (1983) Antifouling agents against the benthic marine diatom Navicula salinicola: homarine from the gorgonian Leptogorgia virgulata, Leptogorgia setacea and analogs. J Chem Ecol 9:817-829

Thaler JS, Karban R (1997) A phylogenetic reconstruction of constitutive and induced resistance in Gossypium. Am Nat 149:1139-1146

Thorson G (1950) Reproductive and larval ecology of marine bottom invertebrates. Biol Rev (Camb) 25:1-45

Van Alstyne KL, Paul VJ (1989) The role of secondary

Editorial responsibility: Otto Kinne (Editor),

Oldendorf/Luhe, Germany metabolites in marine ecological interactions. Proc 6th Int Coral Reef Symp 1:175-186

Van Alstyne KL, Paul VJ (1992) Chemical and structural defenses in the sea fan Gorgonia ventalina: effects against generalist and specialist predators. Coral Reefs 11: 155-159

Warner RR (1997) Evolutionary ecology: how to reconcile pelagic dispersal with local adaptation. Coral Reefs 16: S115-120

Wilsanand V, Wagh AB, Bapuji M (1999) Antibacterial activities of anthozoan corals on some marine microfoulers. Microbios 99:137-145

Yu JK, Wang HY, Lee SC, Dai CF (1999) Genetic structure of a scleractinian coral, Mycedium elephantotus, in Taiwan. Mar Biol 133:21-28

Yunchang L, Kiddle G, Bennett R, Doughty K, Wallsgrove R (1999) Variation in the glucosinolate content of vegetative tissues of chinese lines of Brassica napus. Ann Appl Biol 134:131-136

Zangerl AR, Berenbaum M (1990) Furanocoumarin induction in wild parsnip: genetics and populational variation. Ecology 71:1933-1940

Submitted: December 18, 2000; Accepted: November 6, 2001 Proofs received from author(s): March 19, 2002 